\title{
The Cultivation of Innovation Ability in General Music Education of College and University Students
}

\author{
Hua Li $\mathrm{i}^{1}$ \\ ${ }^{1}$ Department of Music, University of Shanghai for Science and Technology, shanghai, China
}

Keywords: Innovation, General Music Education, Colleges And Universities, College Students.

\begin{abstract}
As with the main sources of innovative spirit, innovative consciousness and innovative ability of high-quality talents, universities should develop students' creative thinking and creative potential from the macro and micro, cultivating innovation ability of the well-rounded college students as the education goals. There are some problems about cultivating college students' innovation ability in general music education, which needs the society, universities and teachers' effort to solve.
\end{abstract}

\section{Introduction}

On October 15th, 2004, General Secretary Xi Jinping emphasized that “Prosperity of literary and artistic creation, and promotion of innovation" during the speech in literature and art work symposium. After two years, On November 30th, 2016, President Xi has raised a claim "Creating more China' s outstanding works that can embody the quintessence of Chinese culture, reflect the Chinese aesthetic pursuit, spread values in modern China and keep pace with the world developing trends $==$. Let our literature and art with distinct Chinese characteristics, styles and manner stands in the world ." as work requirements for literary and art workers once again during the ceremony of the 10th Congress of the China Federation of Literary and Art Circles(CFLAC) and the ninth Congress of the Chinese Writers Association (CWA) address. If the guiding ideology puts into practice to general music education in colleges and universities, it will be shown that teachers will create beauty, cultivate college students' ability of innovation and creativity as their own duty. They will also inherit and carry forward the national folk art with Chinese characteristics to improve the cultural confidence.

As training with innovative spirit, innovation sense and innovative ability of main position of high-quality talents, universities should develop students' creative thinking and creative potential from the macro and micro, cultivating innovation ability of the comprehensive development of college students as the mission and education goals. There are some problems about cultivating college students' innovation ability in colleges and universities general music education, which needs the society, universities and teachers for the effort.

Firstly, The present situation of College Students' innovation ability and music accomplishment

In order to know college students' innovative ability and music literacy understanding, the author from 5 universities (non music colleges) selected 200 college students conducted a questionnaire survey, and interviews with 12 college music curriculum, the Communist Youth League, art education center teacher. Survey results show:

Colleges and universities pay more attention to the cultivation of College Students' innovation ability, but the result is not good enough.

In order to strengthen the cultivation of College Students' innovative ability, some colleges and universities set up a course of innovation and entrepreneurship for college students. According to the survey, there are a lot of such courses, but some of the curriculum for students to enhance the ability to innovate is not significant.

The current situation of College Students' music literacy is not optimistic, and the innovation ability of music is rather weak

According to the results of the survey, only $16 \%$ of the students can quickly and accurately identify the roll numbered, more than $80 \%$ students can identify slowly, only $9.4 \%$ of the college 
students can accurately identify the rhythm, grasp the rhythm of nearly six pairs of small, there are more than 30\% completely cannot read rhythm; most students know something about Chinese traditional music such as local opera, folk songs and local drama, but there are nearly $10 \%$ do not understand the traditional music, even on behalf of the opera of their hometown. When talking about knowledge of music, such as musicians, classic creation background, most of the students have some understanding, but only little. These reserves of music literacy is the cornerstone of innovation in music, if the cornerstone is weak, it is difficult to enhance the ability to innovate.

Secondly, general music education of colleges and universities has a problem in the process of training college students' innovative ability.

Music teachers don' t pay enough attention to their own innovation ability to ascend, and their sense in training Innovative talents is weak.

Some general music education teachers are taught the same course for many years, and their teaching plan and teaching courseware with only very few changes, teachers rarely participate in studying and training so that they are not in line with the forefront of talents training mode, music knowledge and teaching skills. In the personnel training, some teachers think that music general education curriculum just as development way of college students' artistic accomplishment, and they don't have to music general education to cultivate creative ability and creative thinking of college students as their own duty.

Music teaching curriculum contents are focused on teaching theory instead of practice.

After interviewing some ordinary university (not a music professional colleges) music general education teachers and found that all have strict teaching rules and regulations, some of which require that the teaching of theoretical knowledge must take a proportion in theory course, and the music education of the non-music professional colleges and universities lack of resources, such as the lack of practice and site condition, music teacher attaches great importance to the teaching of music theory is better than music practice so student can' $t$ use practice to consolidate the theoretical knowledge then they lack of the most easy to occur in the practice of "re-creation"

Music teaching curriculum methods are not enough and it doesn' t emphasize students' autonomous learning.

Survey of most of the music teaching method curriculum mainly teaching method and demonstration method, rarely with discussion method 、 reading tutoring method v visiting method, practicing method, etc. Students in class aren't given too many opportunities to use their brain more and hands-on and autonomous learning, which makes the students difficult to digest or quickly forgotten teachers teaching content. Music knowledge reserves is insufficient, weakened the creation of the college students and create enthusiasm.

Music general course examination and evaluation ways are old, non-systematic and it does not emphasize student' s individuality.

Survey found that most of the music curriculum is given priority to with the oral examination way, written test is complementary, the main content of music theory knowledge, music, musicians, masterpieces of music, performances, essay, etc. Basically the same course of the class in the form of a single, one size fits all, not according to the student's professional background and personality preferences to design different form that more can stimulate the students' creativity assessment and evaluation methods.

Thirdly, there are some ways for the general music education to cultivate college students' innovative ability.

The cultivation of the college students' creative ability and innovative thinking is one of the important goals of general music education, teachers should put the goal and concept throughout the whole process of teaching. After the author discussed with general music education and university teachers and some college students then combined with their own teaching experience for many years in cultivating college students' innovation ability, have the following conclusion:

Strengthen the ability training of music teachers, master the cutting-edge talent-training philosophy. 
Innovation ability first must have the innovation senses, teachers are regarded as students' soul' $\mathrm{s}$ engineers, they should strengthen their innovation consciousness, and constantly carrying out a research into the creative study. Colleges and universities should set up teacher's teaching development center, we regularly organize education idea, training mode of seminars, create and encourage teachers to participate in all kinds of the relevant training education concepts to strengthen teachers' production, let music teachers go out of the campus, to the enterprise to understand the modern society needs talents type.

Weaken the importance of music professional teaching materials, strengthen teaching practice

Innovation requires theoretical knowledge as the foundation. Different types of colleges and universities, different ages, different areas of college students, the reserves of music knowledge, such as the Yangtze river delta region of the college students' music knowledge reserve is significantly higher than other regions, liberal arts college students is significantly higher than in science and engineering college students, junior college students is higher than that of senior college students. Many of professional teaching pertinence is not strong, not easy to grasp, teachers should arrange the teaching contents according to the characteristics of students, questionnaire survey should do first before the teaching activities, to study the status quo of music knowledge reserve of class and students' interest preferences, according to the survey arrangement and adjust the teaching content. Practice is the important source of innovation, general music education as a means of aesthetic education, college students only through practice to feel beauty, which in turn can create beauty. On the teaching schedule, teachers should strengthen practice teaching, and encourage college students to participate in face-to-face music game or activity, such as college students, original music competition, talent competition, etc., continuously consolidate and test in practice music theory knowledge, to lay the foundation for college students' innovation.

Develop teaching methods innovation, strengthen interaction, cultivate the students' independent learning ability

Teaching methods and means have a lot in general music education, a variety of teaching methods should be combined, according to the characteristics of students innovation. Teachers in teaching should strengthen the training of creative methods, such as when you meet the good concert organization students view appreciation; In the teaching to students' independent learning space, under the guidance of teachers, let the students to participate in lectures, and encourage the student to a music phenomenon, theory, and even the teacher lectures question and so on; Continuously to cultivate college students' creative thinking, combining with the teaching content design the teaching link of imagination, such as story solitaire, give a scenario lets the student writers, on the basis of the music-culture begin writing music, etc. Diverse the teaching methods, which can not only arouse the enthusiasm of students learning, also can cultivate students' creativity.

Combine multiple assessment and evaluation methods, encourage the students to design their self-evaluation

At the end of the course, teachers should try to avoid a single way of examination and evaluation, teachers can be students should have basic knowledge of the theory of regulation for the study project, design more than three other add try another way, can even let the students design their own inspection way, and to give students their own inventions, very rare, but it can reflect the ability of music examination way high evaluation. Let the students master the basic theories of music while increasing confidence and ability to innovate.

In conclusion, colleges and universities should develop education environment that will benefit training of students' innovation sense and innovative ability, with innovative education ethic to accelerate the reform of course system and teaching. Teachers of general music education should cultivate and train students' innovation sense and innovation ability throughout the whole teaching process, and work together to develop college students that meet the requirements of the new era. 


\section{Acknowledgement}

Fund project : This paper is the result of the research project of teachers' teaching development in University of Shanghai for Science and Technology (project number: CFTD17022Z).

\section{References}

[1] Gong Zhen, college students' innovative ability training method and through research, journal of JiangXi youth vocational college, in December 2013, 23 (6) .

[2] WenSheng Hu \Dong Mei, discusses the cultivation of innovative talents in university education is professional space-time, June 2016 .

[3] HuiHua Liu, the problem of university innovation education and the implementation of the strategy analysis, journal of XiangTanUniversity (philosophy and social sciences edition), May 2008. 